\author{
Research Article \\ www.ijrap.net
}

\title{
CLINICAL EVALUATION OF MUHURMUHUR PRAYOGA OF PUSHKARAMULASAVA DURING THE ATTACKS OF TAMAKA SHWASA (BRONCHIAL ASTHMA)

\author{
Shrilatha Kamath ${ }^{1 *}$, U. N. Prasad ${ }^{2}$
} \\ ${ }^{1}$ Associate Professor, PG Department of Kayachikitsa, S.D.M. College of Ayurveda, Udupi, India \\ ${ }^{2}$ Principal and Professor, PG Department of Kayachikitsa, S.D.M. College of Ayurveda, Udupi, India
}

Received on: 07/12/13 Revised on: 23/01/14 Accepted on: 26/02/14

\author{
*Corresponding author \\ Dr. Shrilatha Kamath, Associate Professor, PG Department of Kayachikitsa, S.D.M. College of Ayurveda, Udupi, India \\ Email: shri9503@gmail.com \\ DOI: $10.7897 / 2277-4343.05107$
}

\section{ABSTRACT}

A clinical study based on the conceptual review of the disease Tamaka shwasa (Bronchial asthma) and its treatment, in particular, to the use of atyayika chikitsa during the episodes and also an evaluation of the immediate role of Pushkaramulasava in the disease tamaka shwasa. Tamaka Shwasa, a disease of the pranavaha srotas is one among agonizing disorders. The management of agony created to the patient during the attacks is a field of concern in this disease. Among the many treatment measures mentioned for shwasa, Shamana using Pushkaramulasava has been selected in this study in a repeated dosage pattern and the effect was evaluated. This study has a single group pretest and post test design where the patients were evaluated before, during and after the treatment. Therapeutic effect was observed using the subjective and the objective criteria's which were graded and analyzed statistically using the paired't' test. The patients were observed hourly during the first four days of treatment and weekly for four weeks. Marked remission of the symptoms of tamaka shwasa was noticed in almost all patients in this study. Thus response by the treatment was statistically significant with $\mathrm{P}$ value $<0.001$ in terms of all the symptoms of the disease. Thus the muhurmuhur usage of Pushkaramulasava is proved to be useful in the condition tamaka shwasa as an immediate line of treatment.

Keywords: Tamaka shwasa, Pushkaramulasava, Bronchial asthma.

\section{INTRODUCTION}

Since time immemorial, the field of medicine is in a constant endeavor to find solutions to the life threatening and agonizing disorders. Tamaka shwasa (Bronchial Asthma) is one such condition wherein acute episodes are seen, leaving the patient in a pathetic situation. Hence managing this acute respiratory condition is always a serious issue for the medical fraternity. The indulgence in the etiological factors leads to the morbidity of vata and kapha dosha which originates from the pittasthana and afflicts the rasa dhatu ${ }^{1}$. The disease afflicts the pranavaha srotas along with udaka and anna and produces blockage to the movement of prana vata ${ }^{2}$. The cardinal features of the disease like dyspnoea, cough and expectoration are manifested with the very typical exacerbations and remission pattern which is diagnostic ${ }^{3}$. Bronchial Asthma is a disorder of the airways causing respiratory hypersensitivity, inflammation and constriction of the smooth muscles in the airway, which includes many cells and cellular elements like mast cells, eosinophils, T lymphocytes, macrophages, neutrophils and epithelial cells leading to the symptoms particularly at night or in the early morning ${ }^{4}$. Asthma is a heterogeneous disease which has an interplay between endogenous and environmental factors. The incidence and disease severity is also genetically determined. A general survey has shown that over 300 million around the world suffer from bronchial asthma, and $3.5 \%$ to $20 \%$ prevalence of the disease is observed in any country. Over 40 million of the Indian population is afflicted from this malady ${ }^{5}$.

\section{Tamaka shwasa chikitsa}

Principles of treatment adapted in Tamaka shwasa include shodhana, shamana, brumhana and rasayana chikitsa ${ }^{6}$.
According to the circumstance any shodhana except sneha basti is mentioned in the disease. Abhyanga sweda, dhumapana, langhana, vata vipareetartha chikitsa like trasana, harshana and also oral medications are referred ${ }^{7}$. As the disease progresses after the sthanasamshrayavastha both dosha and vyadhi pratyaneeka chikitsa are needed. As the disease presents with emergency symptoms like shwasa, kasa, ghurghuraka which can also be life threatening, the management should be in such a way that it should give immediate relief to the patients ${ }^{8}$. This type of treatment should later be continued with the shamana or the shodhana line according to the fitness of patient. The wide range of medicaments explained can be classified on the basis of their usage during vegavastha and avegavastha. Among the many shamana procedures oral medication Pushkaramulasava ${ }^{9}$ is identified to be very helpful in relieving the symptoms of the disease.

\section{MATERIALS AND METHODS}

The episodic disease Tamaka Shwasa is best managed by the different atyayika measures mentioned in the chikitsa of the disease. Among the different measures mentioned, Pushkaramulasava in a repeated dosage pattern ${ }^{10}$ was selected as an immediate management therapy in this study. Thus a clinical study was undertaken on 30 patients to evaluate the immediate effect of the treatment on the symptoms and signs of the disease in tamaka shwasa. Ethical clearance was taken from the ethical committee with respect to the study. Institutional ethical clearance number: SDMCAU/ACA15/EC27/09-10.

\section{Aims and Objectives}

To evaluate the immediate effect of Pushkaramulasava in relieving the symptoms of Tamaka shwasa 


\section{Study Design}

\section{Single group pretest posttest design}

30 Patients fulfilling the diagnostic and inclusion criteria of Tamaka shwasa of either sex, irrespective of their economical status, educational status and caste were selected, registered from OPD and IPD of S D M Ayurveda Hospital, Udupi, India and taken for study. Medicine required for the study i.e. Pushkaramulasava was prepared in the S.D.M. Ayurveda Pharmacy.

\section{Diagnostic Criteria}

Patients having cardinal features of Tamaka Shwasa i.e., Shwasa, Kasa, Steevana and ghurghuraka shwasa fitting into the diagnostic criteria fixed by the GINA ${ }^{11}$ guidelines

\section{Inclusion Criteria}

- Patients fulfilling diagnostic criteria of the disease

- Age between $16-70$ years

o Patients having history of more than 6 months

\section{Exclusion Criteria}

- Tamaka Shwasa associated with complications

- Severe attack of Tamaka Shwasa having the peak flow expiratory rate of $<50 \%$ of predicted value of the peak flow rate chart. ${ }^{12}$

- Suffering from systemic disorders which would interfere with the studies

\section{Intervention}

All the 30 patients were treated with Pushkaramulasava for a maximum of 4 days ( $1^{\text {st }}$ day to $4^{\text {th }}$ day) with hourly intervention during the day. A total dosage of $150 \mathrm{ml}^{13}$ was given to the patients in 10 divided doses. Later it was followed by the same medicine in $50 \mathrm{ml}$ tid dosage for 4 weeks ( $5^{\text {th }}$ to $32^{\text {nd }}$ day).

\section{Study Duration}

4 days +4 weeks - Observation -I stage-Hourly, II stage-weekly, follow up 30 days,

Total duration 62 days.

\section{Assessment criteria}

Subjective and objective parameters were assessed before treatment, during treatment on the first, second, third day and fourth day every hour and weekly for the next 4 weeks, adapting standard methods of scoring and were analyzed. Subjective parameters like Dyspnoea, Cough, Speech, Wheeze, Body position and Objective parameters like PEFR, Sputum, Respiratory Rate, Labored breathing, Chest expansion and Breath sounds were considered. Patient was given a complete information sheet consisting the details of the study and a consent form was signed with duly filled details.

\section{Statistical test}

For the statistical analysis of results, paired t test was applied on the parameters of the patients treated with Pushkaramulasava to compare the results within the group before and after the treatment.

\section{Assessment of severity \\ Grade 0 - Nil}

Grade I- Mild intermittent

Symptoms $\leq 2$ times a week

Asymptomatic and normal PEF between exacerbations

Exacerbations brief (few hours to days) intensity may vary

Night time symptoms: $\leq 2$ times a month

Lung functions: PEF $\geq 80 \%$ predicted

$\mathrm{PEF}$ variability $<20 \%$

Grade II - Mild Persistent

$>2$ times a week but $<1$ time a day

Exacerbations may affect activity

Night time symptoms $>2$ times a month

$\mathrm{PEF} \geq 80 \%$ predicted

PEF variability 20-30\%

Grade III -Moderate Persistent

Daily symptoms

Daily use of inhaled short-acting beta -agonist $_{2}$

Exacerbations affect activity

Exacerbations $\geq 2$ times a week; may last days

Night time symptoms $>1$ time a week

PEF $>60 \%-<80 \%$ predicted

PEF variability $>30 \%$

Grade IV -Severe Persistent

Continual symptoms

Limited physical activity

Frequent exacerbations

Night symptoms-Frequent

$\mathrm{PEF} \leq 50 \%$ predicted

$\mathrm{PEF}$ variability $>30 \%$

\section{RESULTS}

All the 30 patients were administered pushkaramulasava and among them 17 patients had to continue with the repeated dosage of hourly medicine for four days and 9 patients got a relief in 3 days and four patients responded within 2 days. On the next day of relief medicine was given in a tid dosage pattern. All the patients were assessed for the change in their symptom scores before, during and after treatment. Statistical analysis was done for the response of treatment on the fourth day and after the whole course on $32^{\text {nd }}$ day. The changes are detailed in the tables and figures. The objective and subjective criteria's of the disease tamaka shwasa were recorded before the treatment of pushkaramulasava and later the patients were observed every hour for the first four days during the day and later weekly for next four weeks. Then the patients were followed for one month to observe for any recurrence. All the parameters taken for assessment showed statistically significant response on the fourth day of assessment. This shows that pushkaramulasava has marked immediate effect on the disease. The statistical analysis on $32^{\text {nd }}$ day also showed significant response in all parameters. This shows that when the medicine is continued the patients get a reduction in the symptoms further. When patients were analyzed on $62^{\text {nd }}$ day of treatment it was observed that very few i.e. four patients 
had recurrence and in other patients recurrence was not observed. The recurrence was seen in the more chronic patients who had a long history of the disease and also who couldn't avoid the daily exposure of allergens due to their occupation. The clinical features like severity, wheeze, speech, body position, labored breathing, respiratory rate and mental status had drastic reduction on the fourth day of treatment and a gradual reduction in the next two weeks. Dyspnoea, ACQ, cough, chest expansion, sputum, PEFR and breath sounds showed gradual reduction on the $4^{\text {th }}, 11^{\text {th }}, 18^{\text {th }}, 25^{\text {th }}$ and $32^{\text {nd }}$ day. The role of atyayika chikitsa is very much identified in diseases like tamaka shwasa which is supported by the mention of repeated dosage pattern of oushadha sevana. Treatment when followed in the specific pattern will help the patients in control of the agonizing dyspnoea.

Table 1: Grading for symptoms

\begin{tabular}{|c|c|c|c|}
\hline SN & Symptoms & Parameters & Grades \\
\hline \multirow[t]{4}{*}{1} & \multirow[t]{4}{*}{ Cough } & No cough & 1 \\
\hline & & Occasional cough but not disturbing & 2 \\
\hline & & Cough troublesome during attacks & 3 \\
\hline & & Cough very troublesome and Frequent & 4 \\
\hline \multirow[t]{4}{*}{2} & \multirow[t]{4}{*}{ Respiratory rate } & Ranging from 12 to 18 breath $/ \mathrm{min}$ & 0 \\
\hline & & Ranging from 19 to 21 breath $/ \mathrm{min}$ & 1 \\
\hline & & Ranging from 22 to 24 breath $/ \mathrm{min}$ & 2 \\
\hline & & More than 24 breath/min & 3 \\
\hline \multirow[t]{5}{*}{3} & \multirow[t]{5}{*}{ Shortness of breath/ breathlessness } & Can walk indefinitely & 0 \\
\hline & & Short breath by strenuous work & 1 \\
\hline & & Short breath by Moderate work (by climbing 1-2 stairs) & 2 \\
\hline & & Short breath by minimum work (by climbing 1 stair) & 3 \\
\hline & & Shortness of breath at rest & 4 \\
\hline \multirow[t]{4}{*}{4} & \multirow[t]{4}{*}{ Body position } & Normal & 0 \\
\hline & & Able to recline & 1 \\
\hline & & Prefers sitting & 2 \\
\hline & & Unable to recline & 3 \\
\hline \multirow[t]{5}{*}{5} & \multirow[t]{5}{*}{ wheezing at day } & No discomfort & 0 \\
\hline & & Once a while in day & 1 \\
\hline & & Twice a day & 2 \\
\hline & & Three to Four times a day & 3 \\
\hline & & More than five times a day & 4 \\
\hline \multirow[t]{5}{*}{6} & \multirow[t]{5}{*}{ Wheezing in Night } & Sleep throughout night & 0 \\
\hline & & Awakened once & 1 \\
\hline & & Awakened twice & 2 \\
\hline & & Awakened three to four times & 3 \\
\hline & & Awakened almost one hourly & 4 \\
\hline \multirow[t]{4}{*}{7} & \multirow[t]{4}{*}{ Use of Accessory muscle } & None & 0 \\
\hline & & Mild occasional use & 1 \\
\hline & & Moderate continuous use & 2 \\
\hline & & Marked excess usage & 3 \\
\hline \multirow[t]{4}{*}{8} & \multirow[t]{4}{*}{ Speech } & Speech Possible & 0 \\
\hline & & Speech- can understand but with difficulty & 1 \\
\hline & & Speech -cannot understand few words & 2 \\
\hline & & Speech- completely slurred & 3 \\
\hline \multirow[t]{4}{*}{9} & \multirow[t]{4}{*}{ Mental status } & Normal & 0 \\
\hline & & Agitated & 1 \\
\hline & & Depressed & 2 \\
\hline & & Coma & 3 \\
\hline \multirow[t]{5}{*}{10} & \multirow[t]{5}{*}{ Quantity of Sputum } & Nil & 0 \\
\hline & & Less than $2.5 \mathrm{ml}$ per day & 1 \\
\hline & & Ranging from $2.5 \mathrm{ml}$ to $10 \mathrm{ml}$ & 2 \\
\hline & & Ranging from $11 \mathrm{ml}$ to $20 \mathrm{ml}$ & 3 \\
\hline & & More than $21 \mathrm{ml}$ per day & 4 \\
\hline 11 & Breath Sounds & None & 0 \\
\hline & & End Expiratory & 1 \\
\hline & & Expiratory & 2 \\
\hline & & Both & 3 \\
\hline 12 & Chest Expansion & $5-8 \mathrm{~cm}$ & 0 \\
\hline & & $4-4.9 \mathrm{~cm}$ & 1 \\
\hline & & $3-3.9 \mathrm{~cm}$ & 2 \\
\hline & & $2-2.9 \mathrm{~cm}$ & 3 \\
\hline & & $<2 \mathrm{~cm}$ & 4 \\
\hline
\end{tabular}


Shrilatha Kamath et al / Int. J. Res. Ayurveda Pharm. 5(1), Jan - Feb 2014

Table 2: Effect of Pushkaramulasava on Different Parameters of Tamaka Shwasa on $4^{\text {th }}$ Day

\begin{tabular}{|c|c|c|c|c|c|c|c|}
\hline \multirow[t]{2}{*}{ Parameters } & \multicolumn{2}{|c|}{ Mean (S.E \pm ) } & \multirow[t]{2}{*}{ DIF in MEAN } & \multicolumn{4}{|c|}{ Paired ' $t$ ' Test } \\
\hline & BT & AT4 & & S.D. & S.E.M. & 't' & $\mathbf{P}$ \\
\hline Severity $\mathrm{N}=30$ & $2.10 \pm 0.14$ & $0.60 \pm 0.12$ & 1.50 & 0.73 & 0.13 & 11.23 & $<0.001$ \\
\hline Dyspnoea $\mathrm{N}=30$ & $2.50 \pm 0.17$ & $1.63 \pm 0.11$ & 0.86 & 0.62 & 0.11 & 7.54 & $<0.001$ \\
\hline Wheeze Day $\mathrm{N}=30$ & $1.83 \pm 0.12$ & $0.56 \pm 0.11$ & 1.26 & 0.74 & 0.13 & 9.37 & $<0.001$ \\
\hline Wheeze Night $\mathrm{N}=30$ & $1.46 \pm 0.12$ & $0.20 \pm 0.08$ & 1.26 & 0.64 & 0.11 & 10.84 & $<0.001$ \\
\hline Speech $N=26$ & $1.23 \pm 0.12$ & $0.23 \pm 0.07$ & 1.00 & 0.58 & 0.10 & 9.32 & $<0.001$ \\
\hline Cough $\mathrm{N}=30$ & $2.600 \pm 0.132$ & $1.500 \pm 0.115$ & 1.100 & 0.481 & 0.0878 & 12.535 & $<0.001$ \\
\hline Body position $\mathrm{N}=30$ & $1.633 \pm 0.122$ & $0.633 \pm 0.131$ & 1.000 & 0.695 & 0.127 & 7.883 & $<0.001$ \\
\hline Labored breathing $\mathrm{N}=30$ & $1.800 \pm 0.147$ & $0.600 \pm 0.123$ & 1.200 & 0.714 & 0.130 & 9.200 & $<0.001$ \\
\hline R.R. $\mathrm{N}=30$ & $1.667 \pm 0.130$ & $0.533 \pm 0.104$ & 1.133 & 0.730 & 0.133 & 8.500 & $<0.001$ \\
\hline Chest exp. $\mathrm{N}=30$ & $1.900 \pm 0.154$ & $1.467 \pm 0.115$ & 0.433 & 0.504 & 0.0920 & 4.709 & $<0.001$ \\
\hline Sputum $\mathrm{N}=30$ & $2.867 \pm 0.196$ & $1.767 \pm 0.133$ & 1.100 & 0.712 & 0.130 & 8.462 & $<0.001$ \\
\hline PEFR $N=30$ & $291.333 \pm 10.567$ & $297.333 \pm 10.526$ & -6.000 & 6.747 & 1.232 & -4.871 & $<0.001$ \\
\hline Mental status $\mathrm{N}=10$ & $0.333 \pm 0.0875$ & $0.000 \pm 0.000$ & 0.333 & 0.479 & 0.0875 & 3.808 & $<0.001$ \\
\hline Breath sounds $\mathrm{N}=30$ & $2.500 \pm 0.104$ & $0.800 \pm 0.162$ & 1.700 & 0.952 & 0.174 & 9.778 & $<0.001$ \\
\hline
\end{tabular}

Table 3: Effect of Pushkaramulasava on Different Parameters of Tamaka Shwasa on 32 ${ }^{\text {nd }}$ Day

\begin{tabular}{|c|c|c|c|c|c|c|c|}
\hline \multirow[t]{2}{*}{ Severity } & \multicolumn{2}{|c|}{ Mean $($ S.E \pm ) } & \multirow[t]{2}{*}{ Difference in Mean } & \multicolumn{4}{|c|}{ Paired 't' Test } \\
\hline & BT & AT32 & & S.D. & S.E.M. & 't' & $\mathbf{P}$ \\
\hline Severity $\mathrm{N}=30$ & $2.10 \pm 0.13$ & $0.000 \pm 0.000$ & 2.100 & 0.759 & 0.139 & 15.157 & $<0.001$ \\
\hline Dyspnoea $\mathrm{N}=30$ & $2.50 \pm 0.17$ & $0.0333 \pm 0.0333$ & 2.467 & 1.008 & 0.184 & 13.403 & $<0.001$ \\
\hline Wheeze day $\mathrm{N}=30$ & $1.83 \pm 0.12$ & $0.000 \pm 0.000$ & 1.833 & 0.699 & 0.128 & 14.367 & $<0.001$ \\
\hline Wheeze Night $\mathrm{N}=30$ & $1.46 \pm 0.12$ & $0.000 \pm 0.000$ & 1.467 & 0.681 & 0.124 & 11.789 & $<0.001$ \\
\hline Speech $\mathrm{N}=26$ & $1.23 \pm 0.12$ & $0.00 \pm 0.0000$ & 1.233 & 0.679 & 0.124 & 9.950 & $<0.001$ \\
\hline Cough $\mathrm{N}=30$ & $2.60 \pm 0.13$ & $0.0333 \pm 0.0333$ & 2.567 & 0.774 & 0.141 & 18.166 & $<0.001$ \\
\hline Body position $\mathrm{N}=30$ & $1.63 \pm 0.12$ & $0.000 \pm 0.000$ & 1.633 & 0.669 & 0.122 & 13.379 & $<0.001$ \\
\hline Labored breathing $\mathrm{N}=30$ & $1.80 \pm 0.14$ & $0.000 \pm 0.000$ & 1.800 & 0.805 & 0.147 & 12.245 & $<0.001$ \\
\hline R.R. $\mathrm{N}=30$ & $1.66 \pm 0.13$ & $0.0333 \pm 0.0333$ & 1.633 & 0.765 & 0.140 & 11.696 & $<0.001$ \\
\hline Chest exp. $\mathrm{N}=30$ & $1.90 \pm 0.15$ & $0.000 \pm 0.000$ & 1.900 & 0.845 & 0.154 & 12.318 & $<0.001$ \\
\hline Sputum N = 30 & $2.86 \pm 0.19$ & $0.133 \pm 0.0631$ & 2.733 & 1.015 & 0.185 & 14.752 & $<0.001$ \\
\hline PEFR $N=30$ & $291.33 \pm 10.56$ & $327.667 \pm 9.752$ & -36.333 & 18.286 & 3.339 & -10.883 & $<0.001$ \\
\hline Mental status $\mathrm{N}=10$ & $0.33 \pm 0.08$ & $0.000 \pm 0.000$ & 0.333 & 0.479 & 0.0875 & 3.808 & $<0.001$ \\
\hline Breath sounds $\mathrm{N}=30$ & $2.50 \pm 0.10$ & $0.000 \pm 0.000$ & 2.500 & 0.572 & 0.104 & 23.924 & $<0.001$ \\
\hline
\end{tabular}
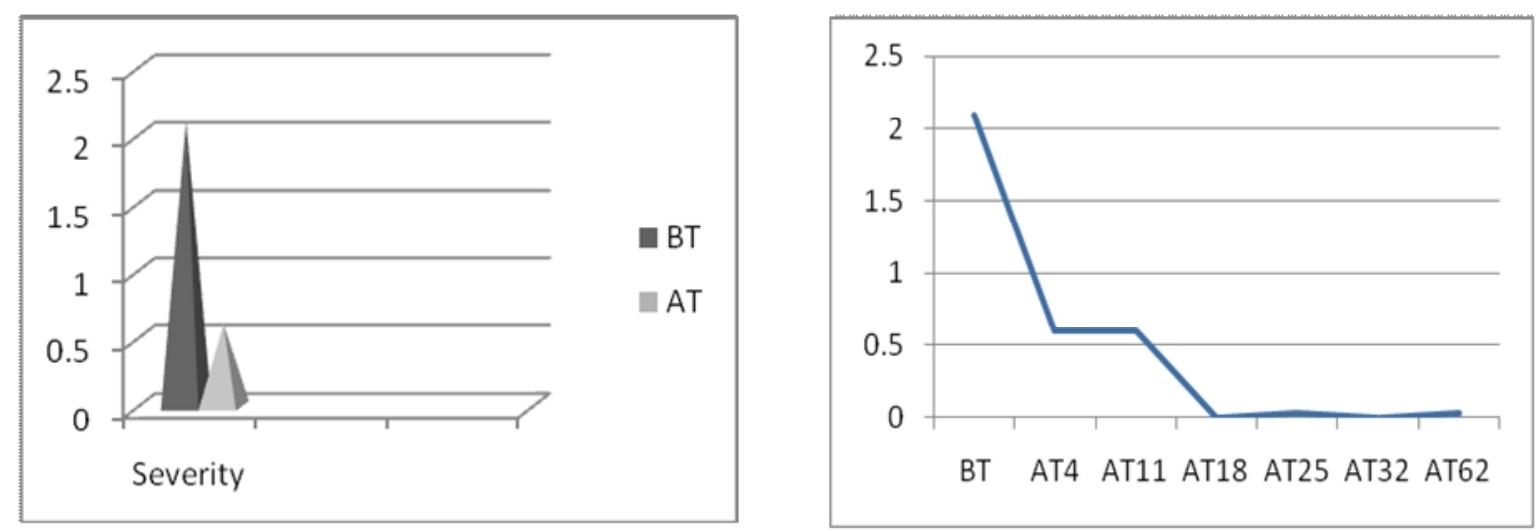

Figure 1 and 2: Effect on severity of disease in patients of Tamaka Shwasa on $4^{\text {th }}$ day and weekly observation 

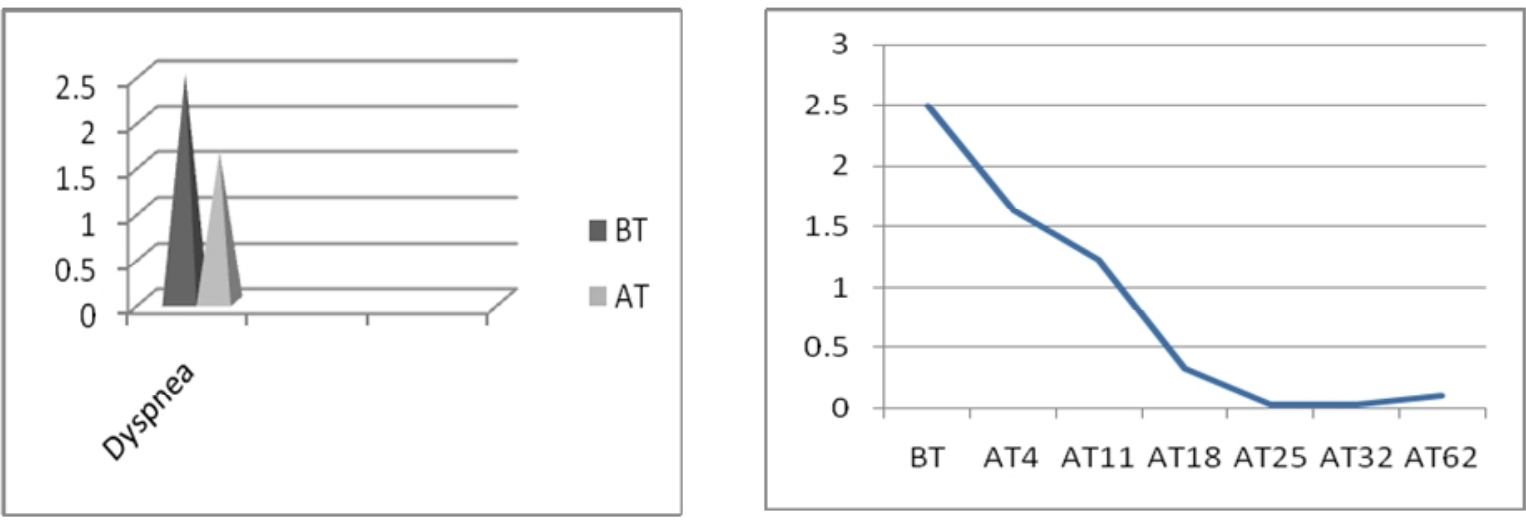

Figure 3and 4: Effect on dyspnoea in patients of Tamaka Shwasa on $4^{\text {th }}$ day and weekly observation
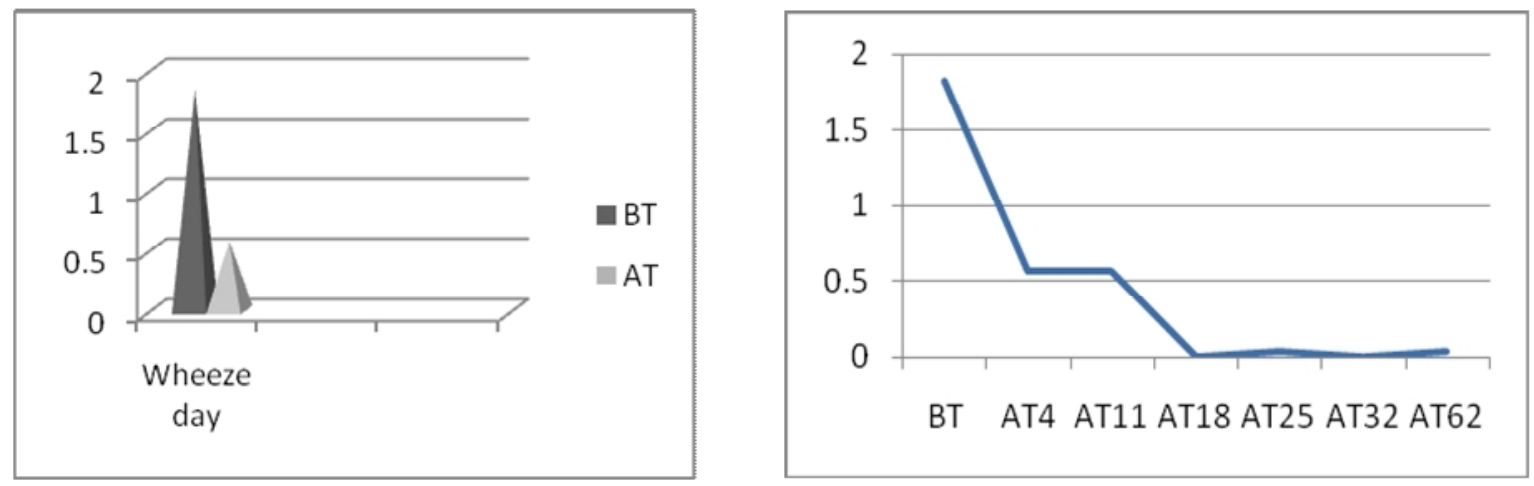

Figure 5 and 6: Effect on wheeze in the day in patients of Tamaka Shwasa on $4^{\text {th }}$ day and during weekly observation
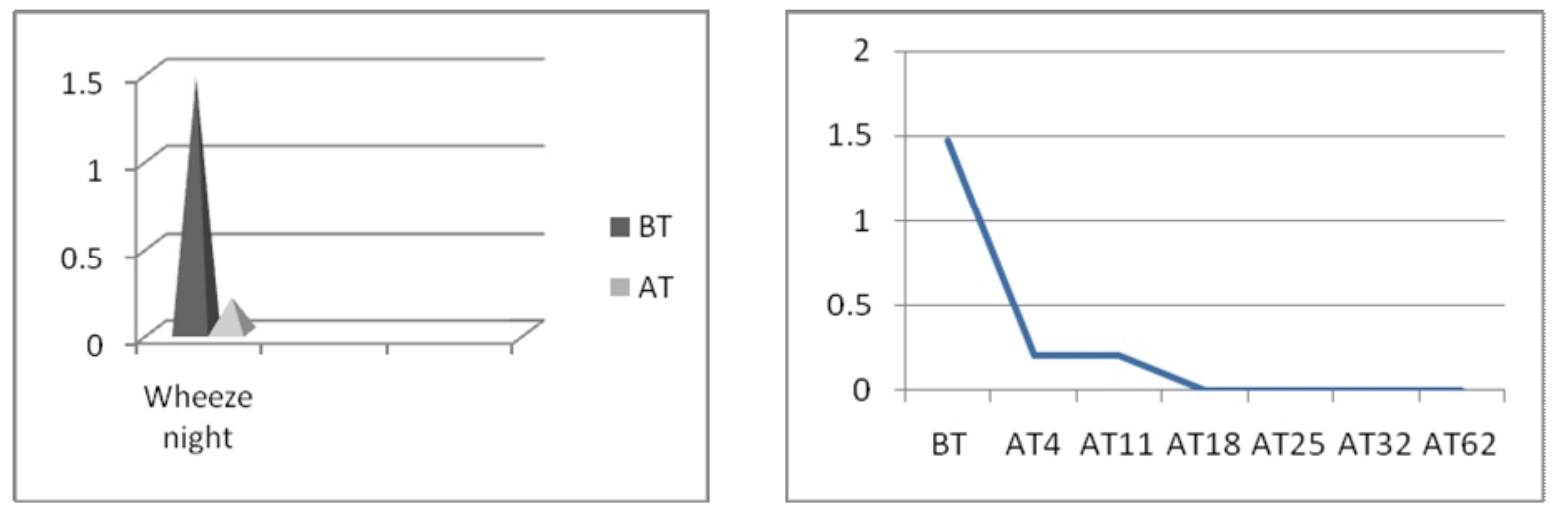

Figure 7 and 8: Effect on wheeze in the night in patients of Tamaka Shwasa on $4^{\text {th }}$ day and during weekly observation 

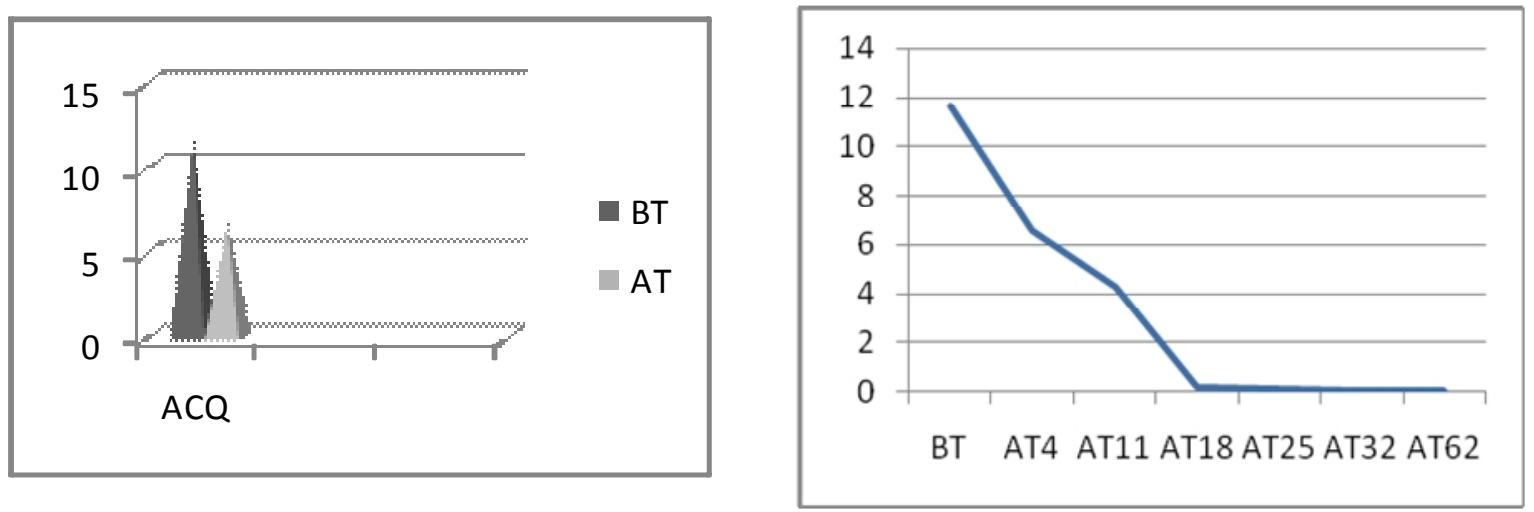

Figure 9 and 10: Effect on Asthma control questionnaire (ACQ) in patients of Tamaka Shwasa on $4^{\text {th }}$ day and during weekly observation
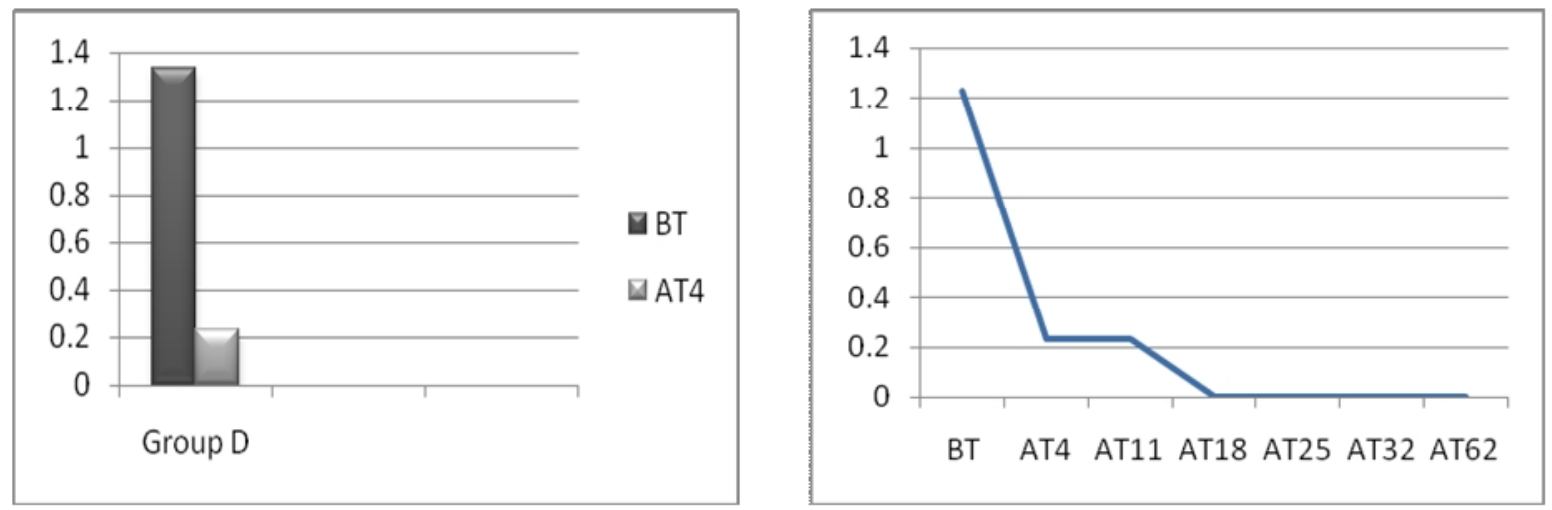

Figure 11 and 12: Effect on speech on AT4 and weekly follow up
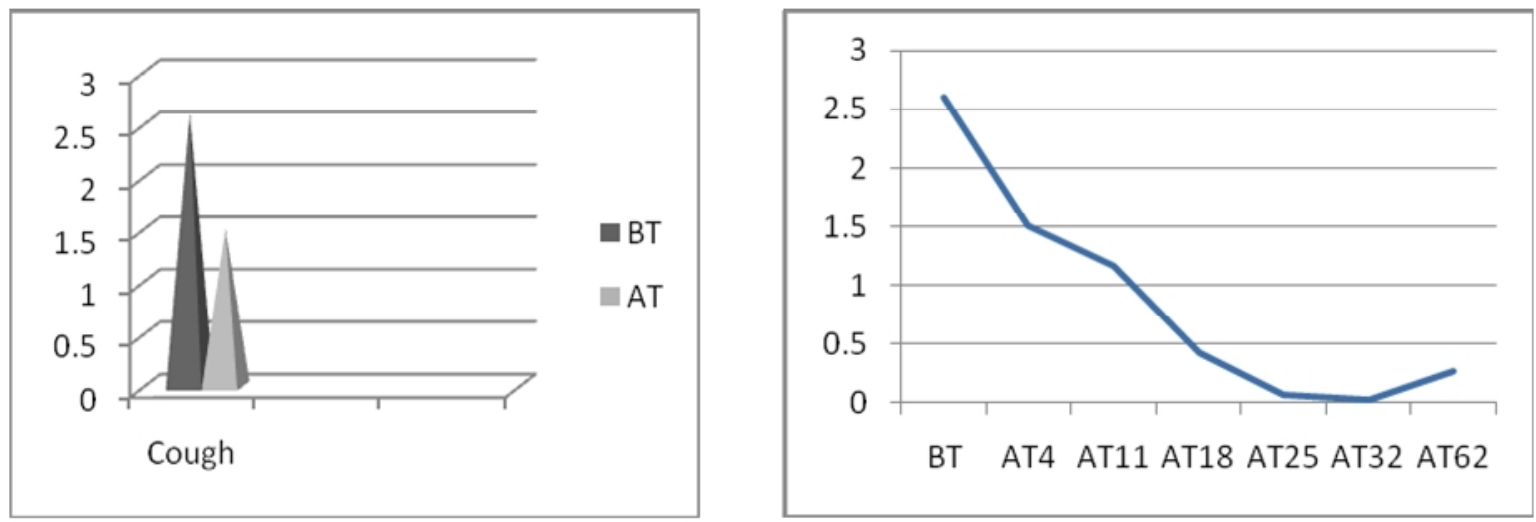

Figure 13 and 14: Effect on cough in patients of Tamaka Shwasa on $4^{\text {th }}$ day and weekly follow up 

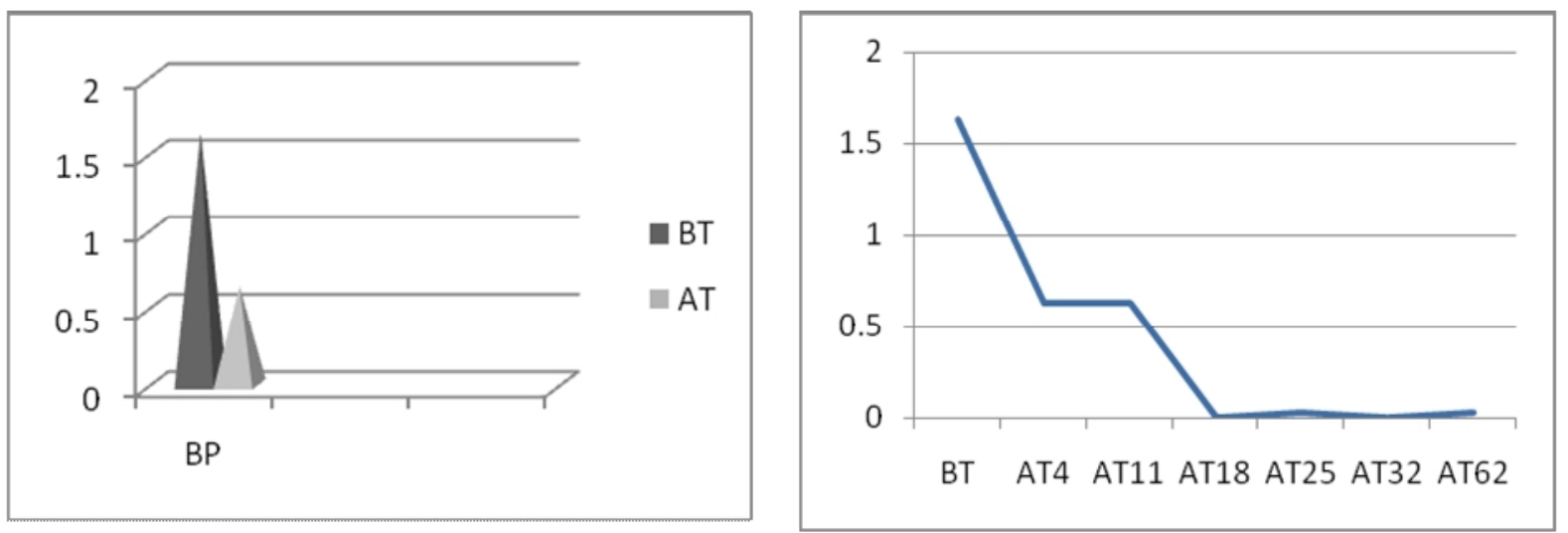

Figure 15 and 16: Effect on body position in patients of Tamaka Shwasa on $4^{\text {th }}$ day and weekly follow up
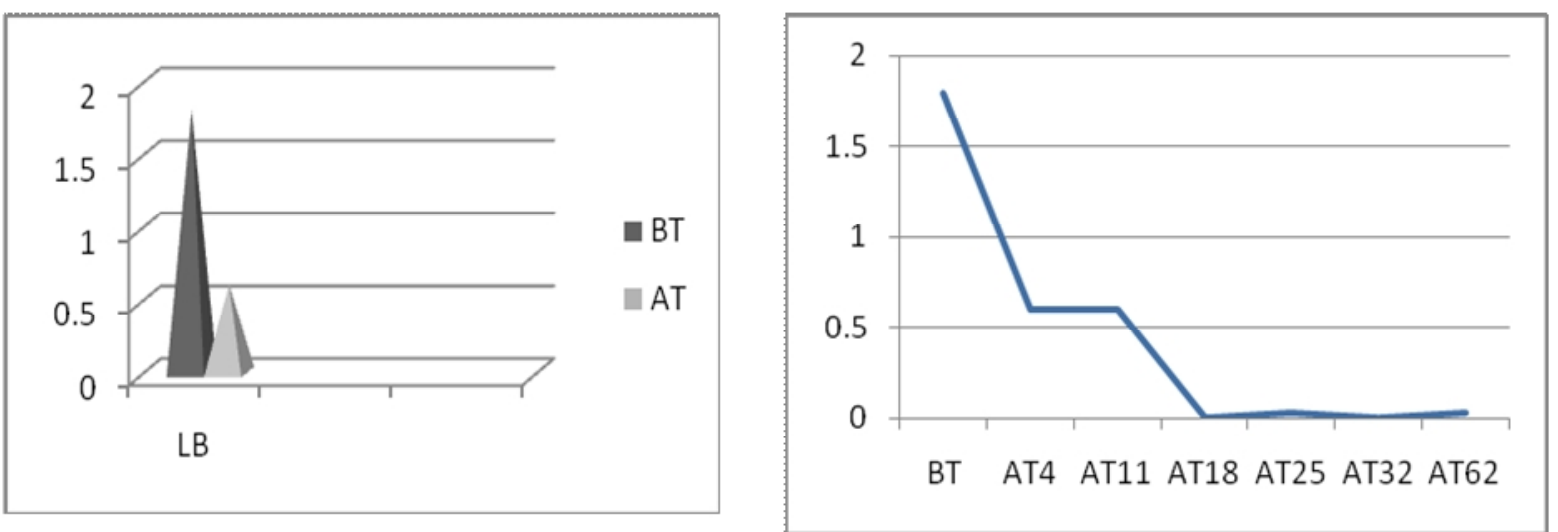

Figure 17 and 18: Effect on labored breathing in patients of Tamaka Shwasa on $4^{\text {th }}$ day and weekly follow up
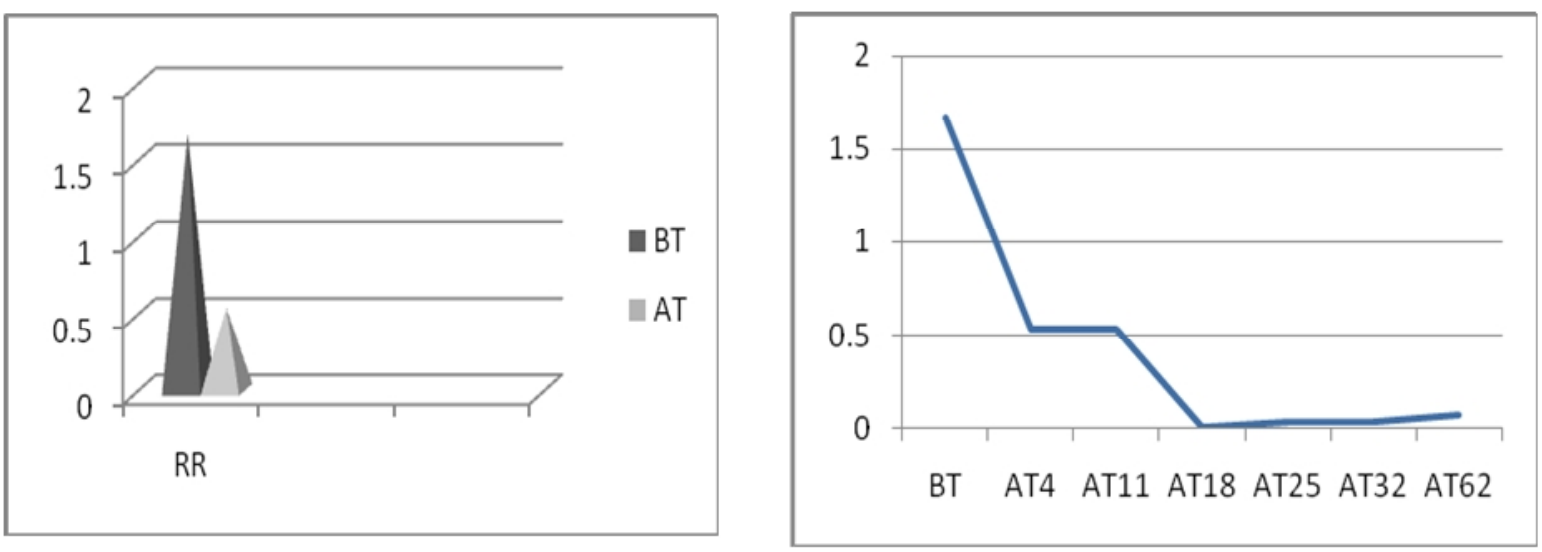

Figure 19 and 20: Effect on Respiratory rate in patients of Tamaka Shwasa on $4^{\text {th }}$ day and weekly follow up 

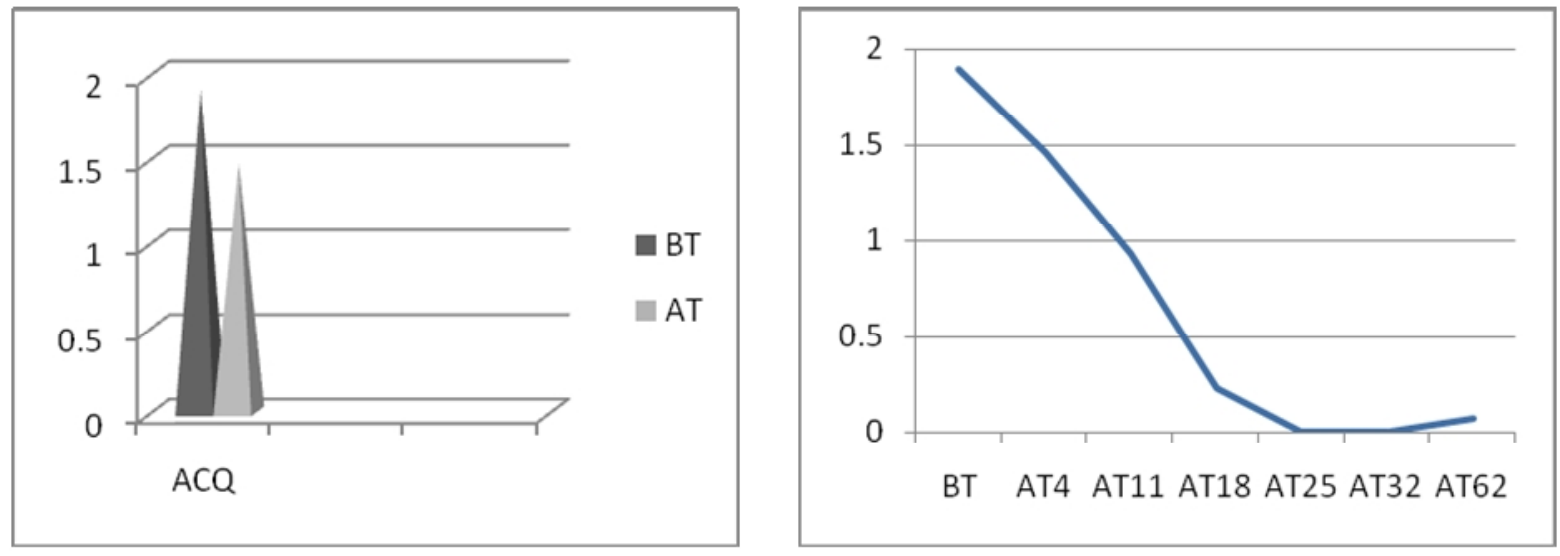

Figure 21 and 22: Effect on chest expansion in patients of Tamaka Shwasa on $4^{\text {th }}$ day and weekly follow up
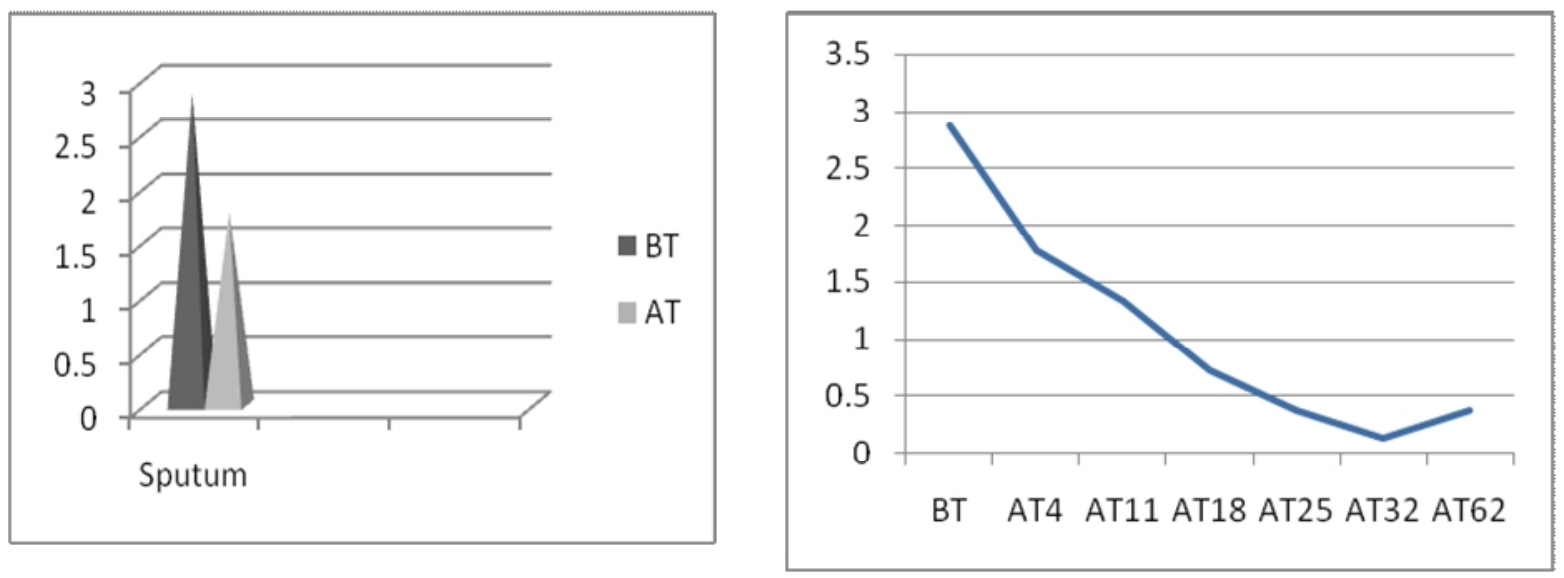

Figure 23 and 24: Effect on sputum in patients of Tamaka Shwasa on $4^{\text {th }}$ day and weekly follow up
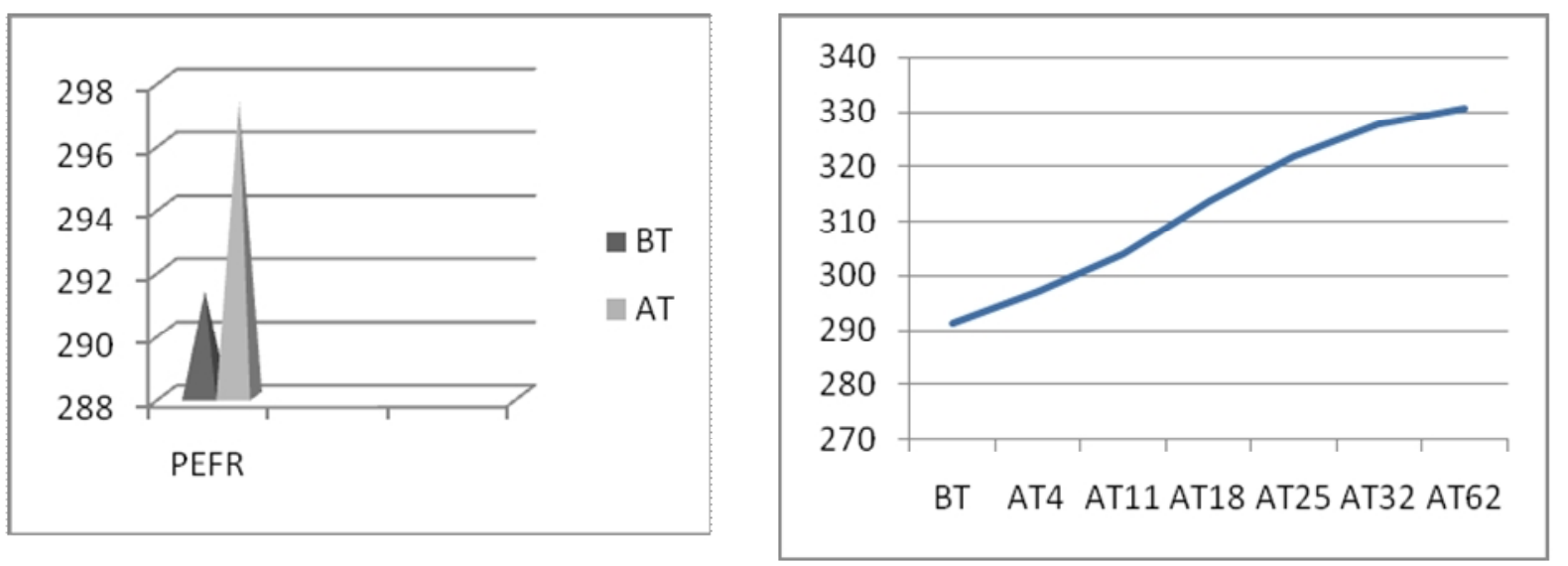

Figure 25 and 26: Effect on Peak expiratory flow rate (PEFR) in patients of Tamaka Shwasa on $4^{\text {th }}$ day and weekly follow up 

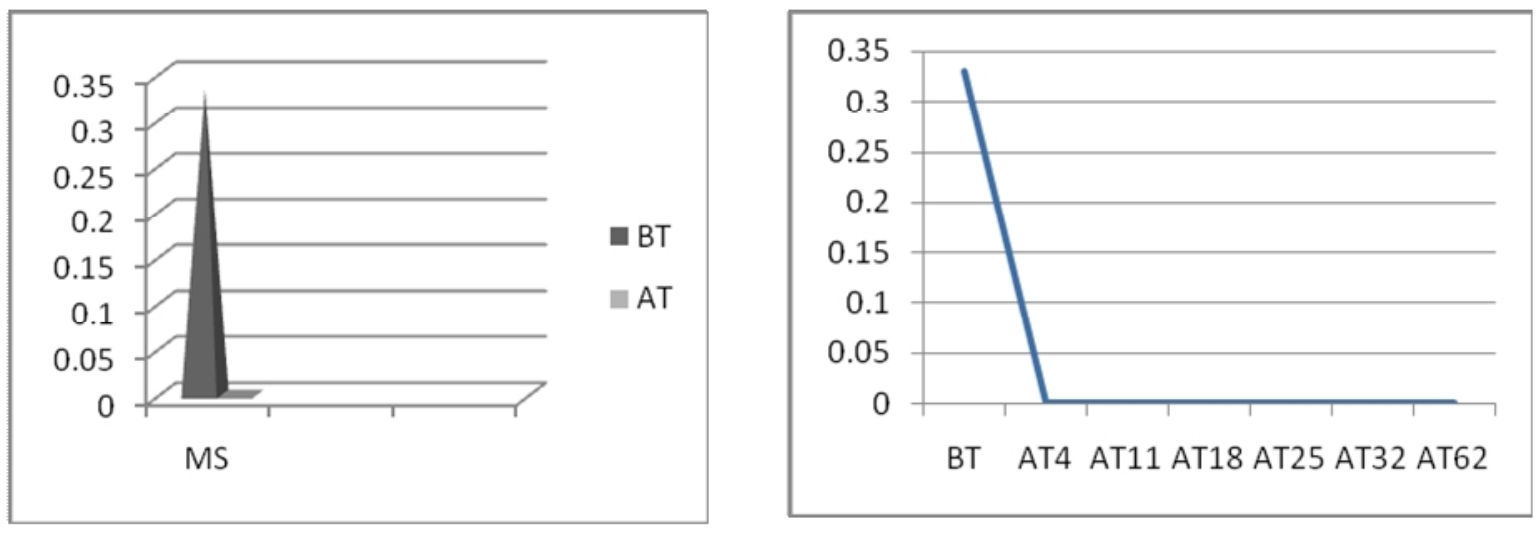

Figure 27 and 28: Effect on mental status in patients of Tamaka Shwasa on $4^{\text {th }}$ day and weekly follow up
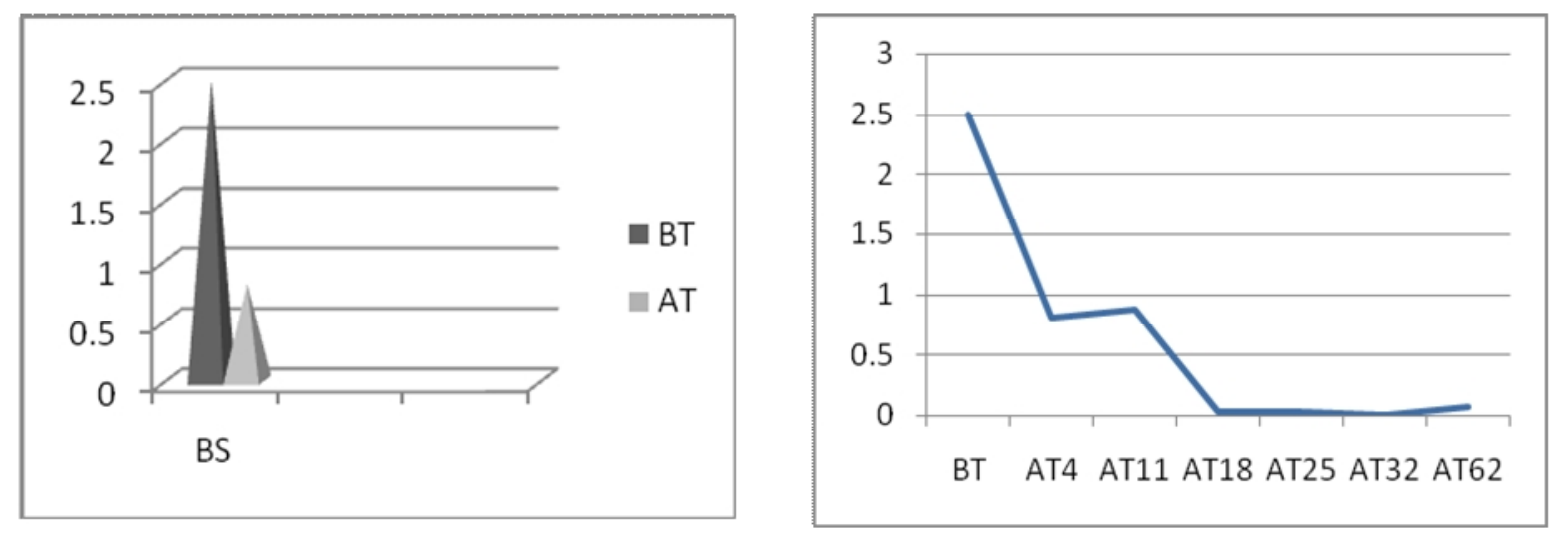

Figure 29 and 30: Effect on breath sounds in patients of Tamaka Shwasa on $4^{\text {th }}$ day and weekly follow up

\section{DISCUSSION}

Tamaka shwasa, a pranavaha srotogata vyadhi afflicting the movement of pranavata, is produced due to the involvement of pitta sthana. The involvement of ama in the early stage of the disease later gets associated with the other dosha vitiations. The disease has an episodic nature which precipitates by the specific nidana in each individual. The factor of atma asatmya is the main culprit in inducing the symptoms. The pathogenesis of shwasa is explained to occur due to the obstruction of the srotas by the kapha leading to the vata vimarga gamana. Thus the pathogenesis prompts the usage of treatment modalities which will work as nidana parivarjna and help in dosha shodhana. The medicaments should have an effect of curing the hypersensitivity prevailing in the individuals. The treatment procedures explained can be identified as ones used during the vegavastha and others used during avegavastha. The immediate management of the disease plans for the cure to the attacks of the disease in giving immediate help. Kapha chedana, vilayana and sroto mardava would help the patients from ghurghuraka, kasa, shwasa and pratishyaya which are considered to be the cardinal features of tamaka shwasa.

\section{Mode of action of pushkaramulasava in tamaka shwasa}

The medicament pushkaramulasava is explained to have kasa, shwasa, parshwashula, hikka, pratishyaya and shophahara action. The medicine consists of amapachana drugs like vyosha, vidanga, chavika and pippalimula, kapha chedaka drugs like vyosha, guda and madhu, pushkaramula, bharangi and kushta which have kasa hara and shwasa hara effect. Several experimental studies have been undertaken to prove the effects of pushkaramula (Inula racemosa) the main ingredient of the formulation. The extract of the drug has shown the anti inflammatory effect against the exudative phase of inflammation in mice. The aqueous and alcoholic extracts have shown the cardio tonic effect in isolated frog's heart. The drug when used in powder form in 50,100 and $200 \mathrm{mg}$ in albino rats has reduced the respiratory rate and increased the depth of respiration. Alcoholic extract has shown protective effect against bronchospasm induced by histamine, 5HT and pollens of zea maize. The medicines in diseases like kasa, shwasa and hikka need to be given in muhu muhu (repeated dosage) pattern which will help in providing a good relief to the patients to their symptoms as it is an episodic disease. The vamana karma along with virechana, brahmana chikitsa and shamana when performed between the attacks, prevents further attacks, eliminates khavaigunyata and improves the immunity of pranavaha srotas. 


\section{CONCLUSION}

The management of the episodes of the disease Tamaka Shwasa was done by shamana chikitsa using Pushkaramulasava in a repeated dosage pattern which helped the patients of Tamaka Shwasa. Hence the clinical evaluation of muhurmuhur prayoga of Pushkaramulasava during the attacks of Tamaka Shwasa (Bronchial asthma) conducted on 30 patients of Tamaka Shwasa for duration of 62 days proved the objective. There was a statistically significant response with $\mathrm{P}<0.001$ in all parameters of the disease which were taken for assessment in the study.

\section{REFERENCES}

1. Acharya Agnivesha, Charaka samhita, Vaidya Yadavji Trikamji acharya, editor, Varanasi: Chaukhambha surbharati prakashan; $5^{\text {th }}$ ed. Chikitsa sthana; 2001. p. 533, 738.

2. Vagbhatacharya, Ashtanga hrudaya, Harishastri Paradakara Vaidya, editor, Varanasi: Chaukhamba orientalia; $8^{\text {th }}$ ed. Nidana sthana; 1998. p. $472,956$.

3. Acharya Agnivesha, Charaka samhita, Vaidya Yadavji Trikamji acharya, editor, Varanasi: Chaukhambha surbharati prakashan; $5^{\text {th }}$ ed. Chikitsa sthana; 2001. p. 535, 738.

4. Anthony S Fauci, Joseph B Martin et al. Harrison's principles of internal medicine. USA: Mc. Graw Hill Companies; $14^{\text {th }}$ ed. (Vol 2); 1998. p. 1420-1422, 2569.
5. Asthma statistics, American Academy of Allergy Asthma and Immunology; 2014.

6. Acharya Agnivesha, Charaka samhita, Vaidya Yadavji Trikamji acharya, editor, Varanasi: Chaukhambha surbharati prakashan; $5^{\text {th }}$ ed. Chikitsa sthana; 2001. p. 537-8, 738 .

7. Vagbhatacharya, Ashtanga hrudaya, Harishastri Paradakara Vaidya, editor, Varanasi: Chaukhamba orientalia; $8^{\text {th }}$ ed. Chikitsa sthana; 1998. p.608, 956.

8. Acharya Agnivesha, Charaka samhita, Vaidya Yadavji Trikamji acharya, editor, Varanasi: Chaukhambha surbharati prakashan; $5^{\text {th }}$ ed. Chikitsa sthana; 2001. p. 533, 554, 738 .

9. Vaidya Mahendra Pal Singh Arya, editor, Sahasra Yoga. New Delhi: Kendriya Ayurveda and Siddha Anusandhana Parishad; 1990. p. 350,621 .

10. Acharya Agnivesha, Charaka samhita, Vaidya Yadavji Trikamji acharya, editor, Varanasi: Chaukhambha surbharati prakashan; $5^{\text {th }}$ ed. Chikitsa sthana; 2001. p. 646, 738.

11. Barbara P Yawn et al, Assessment of Asthma Severity and Asthma Control in Children, Pediatrics 2006; 118: 322-329.

12. American lung association. Peak Flow Meters; 2014.

13. Sharngadharacharya, Sharngadhara Samhita, Parashurama Shastry Vidyasagar, editor, Varanasi; Chaukhamba orientalia; $7^{\text {th }}$ edition. Madhyama khanda; 2008. p. 233, 398.

Cite this article as:

Shrilatha Kamath, U. N. Prasad. Clinical evaluation of Muhurmuhur prayoga of Pushkaramulasava during the attacks of Tamaka shwasa (Bronchial asthma). Int. J. Res. Ayurveda Pharm. 2014;5(1):26-35 http://dx.doi.org/10.7897/2277-4343.05107 